\title{
A Lesbian is a Memoir
}

\author{
Lou Robinson
}

\section{Une lesbienne est une mémoire}

Une lesbienne est une mémoire. Une lesbienne est des mémoires. Tout qu'une lesbienne écrit organise ou vole et colle est lu comme une autobiographie, pathologique, sexuée et déjà tracée. Ces fragments collés en guise d'autobiographie se lisent plutôt comme un train-

I paste a picture of a shy chocolate fanaloka over an account of murder from the Ann Arbor News. A woman was arrested in Toronto for attacking a man with a cordless drill. the remote fanaloka (fossa fossa) is Mary, thus I make balance.

Mary was a model waitress. Her short black hair on a long white neck, a French neck, a cinema neck. It was a cinema town. I am twenty-one. Mary wipes down her tables at 3 a.m. She dunks her whole head in the sink, a palmful of gardenia shampoo, a good catholic girl on whose marble body no amount of depravity dare leave a mark. Glistening, she makes me a Pimm's cup to buoy me up as I scrape the grill with the block, steaming my face with the smell that dogs always follow, after I leave her. Mary took the fall for all the friends who brought Flaming Creatures to the screen and were arrested for obscenity. On the stand, what man could send the Virgin Mary to jail? He could do worse. One of her jurors. Terrible hair low on the forehead, followed her to our bar. This will never have happened, because of the panther I have placed between them. Along the margin of a ripped piece of the Ann Arbor News the words: 'touched by her testimony.' touched. 'She likes to have her face touched,' Mary announced one night after closing. To my invisible future comers. She didn't like me to use big words like closure, synchronicity. Am I pasting for Mary? No, I make balance. I make everything up.

Mary had been writing her memoirs by tossing scraps of paper into a box. Some original notes, some things overheard. Names of Motown 


\section{A Lesbian is a Memoir · 71}

groups she was inventing. Pictures of herself naked in the rafters in karate postures. As long as she was in the body cast, she was a lesbian. Only a finger could enter her. Men at dawn on the porch photographed her bike after removing the light. She lost the suit against the man who hit her. When I came home from the bar she'd say'I creamed myself in my cast, give me a kiss.' There was an Alaya, how to spell it, that she had loved. If I could find Aleia now I could write Mary's memoirs because at least half that boxful was mine or Eliya's. And we'd call it My Own Story by Teeny Chiffon.

A lesbian is a memoir. Anything a lesbian writes arranges or steals and pastes is read as autobiography, pathology, already sexed and traceable. Mine will be more like a train.

Two years before, in the bathroom mirror in Athens, Ohio, I had seen every one of my years to come, nineteen to ninety, speeding by blue and red in veins suddenly visible beneath transparent skin stretched tight with astonishment at so much momentum, exactly how it would look: frowning, fierce, adamant about the body's right and every woman's body's right to be inhabited and to press them together. The word that rose then was not 'right' but vehicle. Then the bathroom door opened to screams, I forgot everything for years. An ice white ibis had been hit in the mouth, his tooth fell in his palm, his palm filled with blood. I drove, steering from as far away as Venus, to the emergency room where I refused to give the name of my gay comrade, Clay, my best friend, son of the man who owned the bowling alley where the football team beat us up, first lover, gay soon after. The doctor and nurses joking about pizza, don't you think these girls would like some pizza, because they knew drugs turned hungry minds to mouths and only girls have mouths. That will go in one compartment.

Trimming around the meager tail of a zebra cut from the National Geographic, I remember National Velvet's paper horses. Don't mistake repetition for balance, I tell myself firmly, pressing two emerald snakes emerging from its mouth and anus. I paste a story (what's a story?) of a pioneer boy consumed by a tapeworm set to die by a bowl of water just out of reach until thirsty enough out it crawls. So much for elementary education. Do they have eyes? Do they have mouths? Can snakes be bandaged? That's all I had to know. Then I could be their angel. What I saw in a mirror in Athens, Ohio - two girls with hair in braids wound around naked breasts, a woman wrapped in foil, 
gay boy dancers making sharper angles, masturbating, one bleeding from the mouth - that was reflected behind me. What I saw in my face, my future, polaroid speed, prophetic, I'd say about $70 \%$ accurate, that was just veins. I was always reading into things. I paste a bazooka gum fortune across the back of an Appaloosa like a soft Sioux Indian saddle; it says 'Angels guard your every step.' Under its hoof I write chain lightning. Is the wild water out there too beautiful? Does it distract you in your furious efforts to understand?

I take a smoking stance against the wall beside the green water with its fawn-coloured foam. I gave up smoking after the accident because lighting up drew eyes to the bent limb. What happened in Ireland was when I was trying once and for all really trying this time to be a man, knocked down and the green twig fracture grew greener bluer yellow sky before a tornado. You are trying so hard not to be a man you go numb. Dead Man I write on your forehead where you stare from your waking sleep.

Mary and I had planned to sleep in the middle of Avebury Circle. 'Where is your protection?' said a boy, a waiter at the pub. We laughed. 'You! you are our protection. Aren't you a man?' 'Brain pudding,' he said savagely. All night long lying among the stones we heard whistling in ever narrowing circles, accompanied by lowing querulous cows sounding as if they knew the normal course of dusk, deep night, dew, had been disturbed at the core of the world. Nuts fell on us like bullets. We were safe as anyone home in the family bed. The great stones grew pink, and still we couldn't read the words.

I said 'water' to Mary when she fell and knocked her head. In her stupor she dreamed I said it, demanded water, water. Now we both believe in it for concussion, for anything, communicating with the dead, the might have been, the far away, for discommunicating, purging, all that. When someone feeds your love to the river. Mary, are you listening? Water. We broke the ice on Lake Michigan, stripped and jumped. Down jackets waiting on the shore in two puffs, one blue one rust. There was another swim in the dark at a Camp Covert. I looked back to see her on shore, two great man shapes alongside, swam furiously to be her protection. They pointed to a beached and twisted boat. 'That got caught in the undertow you just swam through,' they said, revealing badges. I can say and Mary was my witness, that I swam through the undertow and out again. But I don't know if I would have had she not been standing whitely on the shore. We have 


\section{A Lesbian is a Memoir · 73}

the double exposure during a photo session in Saginaw Woods, me clutching a bundle of rags, white paint on my face, her with branches in her hair and camera in front of her face. It was a charm for disappearing and truly the edges of Mary are beginning to blur. But when the edges disappear, the substance can really travel. No, this accident was later, near Duncannon, Ireland, a little interior snap. It won't appear here.

A memoir can be made the same way. Take any novel and pretend it's autobiographical. Take some things out, put some things in. A lesbian is a woman who reads without respecting anything. Where is the authority in these words? A lesbian or a memoir neither has nor answers to authority. A lesbian is a memoir in the eyes of the world. Someone can make you a lesbian by saying 'I thought so because of the way your mouth turns down when you smile.'

'Who wants to read about all the women she was with?' your mother asked you. Answer, 'I have been with 2283 women.' Two squirrels girdling a tree in a day and half felled 2283 twigs to get at seeds. The tree with all its pendant spheres is starting to topple because of all the women I have girdled and trimmed. Two thousand two hundred and eighty-three women. Think about it. You're forced to.

In a Chinese restaurant in San Francisco and I asked Mary how many she said,' oh not many, 50 .' I said I thought 22 was too many. She said 'well Clay lost count at 4,000, so why do you feel sin? We were pioneers.' Her fortune said 'your lover will never want to leave you.' Mine was a blank white strip. A moment came back to me. A passage in Delta of Venus read standing up in Borders Bookstore. The bathroom in Jacobson's across the street to get off. In the stall next a woman in high heels facing the toilet like a man. Sound of pissing. What is a lesbian, I was still asking myself at twenty. So I asked the heels, 'can you tell me what a lesbian is?' He passed me a tube of lipstick called walnut and I knew that meant Hester Prynne, a lesbian is a prostitute, because Hester stained her lips with walnut juice. English majors run to their texts. Nothing. See, to a memoir, literature is not sacred. I read it, it became mine, it lay with the others and merged as memoirs are wont. Who can say. Who can say what? Who can say what a lesbian is. A memoir is a manifesto is a lesbian fucking literature.

You. Sleep with 2283 women. Girdle the tree of life below the snow 
line and strip it, watch it fall. Sleep with 22 men and live to tell. Feel as little love as possible, even for the tree circled with ivy, the one that watched over you that comforted and rocked you and said s/he'd never leave her strangle it at the root.

Memoirs are not romantic. Even when they wallow they fail. The flat statement at the soul of the memoir is I can't feel. The lesbian can relate sentimental facts. But to write romantically the lesbian must be an author this is a contradiction in terms. No I. A memoir cannot refer to another with any objectivity. There is no other. A memoir that begins You ...

When a memoir reaches out to an ephemeral other, books fly off the shelves into your arms, a great love, state of grace, ravages, night, a dusty answer. Led to believe we stave off the natural rot by loving women carefully, correctly. I mean, in all their diversity, confusing them with us. Violent loving, lesbians believe, disintegrates the integrity of the memoir, writing itself at the kitchen table this very moment, inserting itself into the underside of history, writing very close together to kill fewer trees. When a lesbian says love he or she means pride of self. A lesbian is a hercules. A lesbian really loving women drops the earth, forests fall. Nothing means anymore. Look what happens. Worse you can't tell who you are. A memoir about really loving is a contradiction in terms, if a memoir is a lesbian. You do this. You make me say these things.

I am writing your memoir I will make you feel, Dead Man. I am in you you are putting down your pen, putting down your coffee. A sharp pain below a rib on the left that's me climbing crossing diagonally. Circling your heart and squeezing. You made me. Wetness on your lashes now, this moment. You are thinking, looking at the steam rising from the lake as from a new corpse, that you have missed the point and maybe it's too late. You don't know what you are. How dare another woman make you feel this way. It's not real. It's only a footnote. Yet you have never been so alone, many times. A pioneer. 